\title{
NOTES ON THE ASH YIELD OF CANNABIS.
}

BY E. I. NEWCOMB, C. E. SMYITHE AND E. R. HODEL.

There are numerous references in the literature relative to the ash yield of Cannabis. For the most part these references are not accompanied with any data relative to the amount of seed contained in the sample, the amount of the ash insoluble in $10 \%$ hydrochloric acid or any information about the general character of the drug being examined. The published data alone are of little value in determining what a practical and workable purity rubric for this drug would be.

We have attempted in this study to obtain data which would be helpful in determining proper ash standards and a satisfactory purity rubric. Commercial samples from a number of different sources have been examined. We have also examined a series of samples obtained from plants grown in the University of Minnesota Medicinal Plant Garden. Unfortunately we have not been able to obtain supplies of imported Cannabis; however, the appended compilation of the results of different workers in part makes up for this deficiency. Our results are as follows:

ASH YIELD COMMERCIAL, SAMPLES OF CANNABIS.

\begin{tabular}{|c|c|c|c|c|c|}
\hline Sample No. & Remarks. & $\begin{array}{c}\text { Percent } \\
\text { tops. }\end{array}$ & $\begin{array}{l}\text { Percent } \\
\text { seed. }\end{array}$ & $\begin{array}{c}\text { Percent } \\
\text { total } \\
\text { ash }\end{array}$ & $\begin{array}{c}\begin{array}{c}\text { Percent } \\
\text { sht } \\
\text { insol. in } \\
\mathrm{HCl}\end{array}\end{array}$ \\
\hline \multirow[t]{2}{*}{95 . } & Whole, Amer., bought 1921 . & 96.0 & 4.0 & 13.73 & 2.97 \\
\hline & & & & 13.71 & 2.98 \\
\hline \multirow{2}{*}{96.} & Whole, Amer., bought 1921. & 97.6 & 2.4 & 12.27 & 2.73 \\
\hline & & & & 12.31 & 2.51 \\
\hline \multirow[t]{2}{*}{97 . } & Whole, Amer., bought $1921 \ldots \ldots \ldots \ldots$ & 83.4 & 16.6 & 13.92 & 2.45 \\
\hline & & & & 13.84 & 1.91 \\
\hline \multirow{2}{*}{111.} & Tops only from No. 97 . & & & 14.67 & 2.17 \\
\hline & & & & 14.63 & 1.84 \\
\hline \multirow[t]{2}{*}{101.} & Whole, Amer., bought 1921. & 70.0 & 30.0 & 13.56 & 3.48 \\
\hline & & & & 13,14 & 3.31 \\
\hline \multirow[t]{2}{*}{113.} & Tops only from No. $101 \ldots \ldots \ldots \ldots$ & $\ldots$ & & 16.81 & 3.69 \\
\hline & & & & 16.44 & 3.18 \\
\hline \multirow[t]{2}{*}{112.} & Old sample commercial powder........ & $\ldots$ & & 16.94 & 7.13 \\
\hline & & & & 16.81 & 6.63 \\
\hline \multirow[t]{2}{*}{100.} & Cannabis Seed, powd. in this Laboratory & $\cdots$ & $\ldots$ & 6.14 & 1.91 \\
\hline & & & & 6.06 & 2.12 \\
\hline \multirow[t]{2}{*}{98.} & Cannabis Seed, powd. in this Laboratory & $\ldots$ & $\ldots$ & 5.93 & \\
\hline & & & & 5.87 & 1.96 \\
\hline
\end{tabular}

ASH YIELLD OF CANNABIS GROWN IN MINNESOTA.

The following figures relate to Minnesota grown Cannabis. The drug was collected in the fall of the year, usually the latter part of September or the first of October; the collecting being done by students. The wild plants grow abundantly in this vicinity and hence it is almost impossible to prevent pollination.

The Garden soil is sandy loam. Clouds of dust blow through the Garden during dry spells. The fine sand sticks to the Cannabis tops. The tops were carefully collected and dried but our ash tests indicate that there is much adhering sand. Due to our inability to remove all staminate plants in the vicinity, seed in varying amounts was always present. If the collection is late in the season we find that the birds have usually taken most of the seed. The Minnesota drug 
is therapeutically active, but considerably more than the present U. S. P. standard dose is required to produce incoördination in a susceptible dog. We have found this to be true with many other samples.

\begin{tabular}{|c|c|c|c|c|c|}
\hline \multicolumn{2}{|c|}{ Minnesota cannabis } & \multirow[b]{2}{*}{$\begin{array}{c}\text { Percent } \\
\text { tops. }\end{array}$} & \multirow[b]{2}{*}{$\begin{array}{l}\text { Percent } \\
\text { seed. }\end{array}$} & \multirow{2}{*}{$\begin{array}{l}\text { Percent } \\
\text { total } \\
\text { ash. }\end{array}$} & \multirow{2}{*}{ 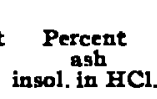 } \\
\hline Samples. & Remarks. & & & & \\
\hline 103. & Univ. of Minn., tops only, 1910 crop... & $\cdots$ & $\cdots$ & $\begin{array}{l}18.04 \\
17.57\end{array}$ & $\begin{array}{l}4.91 \\
4.15\end{array}$ \\
\hline 104. & $\begin{array}{l}\text { Univ. of Minn., tops only, } 1910 \text { crup, } \\
\text { exhausted with alcohol............. }\end{array}$ & & & $\begin{array}{l}16.22 \\
16.23\end{array}$ & $\begin{array}{l}3.17 \\
2.88\end{array}$ \\
\hline 115 . & 1913 crop, whole drug, tops and seed.. & 79.0 & 21.0 & $\begin{array}{l}16.08 \\
15.96\end{array}$ & $\begin{array}{l}4.28 \\
4.29\end{array}$ \\
\hline 116. & Tops only from No. 115. & $\cdots$ & $\cdots$ & $\begin{array}{l}17.88 \\
18.00\end{array}$ & $\begin{array}{l}4.08 \\
4.405\end{array}$ \\
\hline 94. & 1914 crop, tops and seed.$\ldots \ldots \ldots \ldots$ & 50.0 & 50.0 & 13.48 & 2.94 \\
\hline 106. & 1914 crop, tops only from No. $94 \ldots \ldots$ & $\ldots$ & $\ldots$ & $\begin{array}{l}15.58 \\
15.70\end{array}$ & $\begin{array}{l}2.72 \\
3.47\end{array}$ \\
\hline 99. & 1915 crop, tops and seed $\ldots \ldots \ldots \ldots$ & 80.8 & 19.2 & $\begin{array}{l}15.85 \\
16.02\end{array}$ & $\begin{array}{l}4.58 \\
3.97\end{array}$ \\
\hline 114. & 1915 crop, tops only from No. $99 \ldots \ldots$ & $\cdots$ & $\ldots$ & $\begin{array}{l}17.57 \\
17.49\end{array}$ & $\begin{array}{l}4.54 \\
5.13\end{array}$ \\
\hline 102. & 1918 crop, practically no seed. . . . . . . & $\ldots$ & $\ldots$ & $\begin{array}{l}17.31 \\
17.91\end{array}$ & $\begin{array}{l}2.53 \\
5.02\end{array}$ \\
\hline 117. & 1919 crop, tops and seed. . . & 90.0 & 10.0 & $\begin{array}{l}17.16 \\
17.18\end{array}$ & $\begin{array}{l}4.42 \\
4.89\end{array}$ \\
\hline 118. & 1919 crop, tops only from No. $117 \ldots$ & $\therefore$ & $\ldots$ & $\begin{array}{l}17.34 \\
17.49\end{array}$ & $\begin{array}{l}3.96 \\
3.83\end{array}$ \\
\hline 119. & 1920 crop, tops and seed......... & 93.0 & 7.0 & $\begin{array}{l}17.75 \\
17.52\end{array}$ & $\begin{array}{l}4.23 \\
3.72\end{array}$ \\
\hline 120. & 1920 crop, tops only from No. $119 \ldots$ & $\cdots$ & $\cdots$ & $\begin{array}{l}18.20 \\
18.00\end{array}$ & $\begin{array}{l}4.11 \\
3.69\end{array}$ \\
\hline
\end{tabular}

The seed was separated by rubbing the whole drug over a screen having meshes of a size sufficient to prevent the seed passing through. A subsequent winnowing completed the separation.

The results of these tests would indicate that under conditions of cultivation it might be quite impossible to meet the present ash standard of 15 percent. On the other hand present commercial samples of American Cannabis appear to usually come within the standard. Some of the high ash contents reported may be due to the same trouble we have of sand sticking to the growing plant.

COMPILED DATA RE ASH YIELD OF CANNABIS.

Rippetoe \& Minor, A. J. P., Vol. 84, p. 437.

Cannabis Indica..................... 14.20

Rippetoe, Smith, Taylor \& Stoddart, A. J. P., Vol. 86, p. 437

Cannabis Americana, $46.75 \%$ seed . . . . . . . . 6.20

$46.75 \%$ seeds

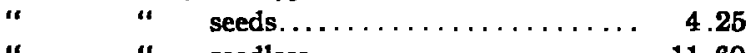

11.60 


\begin{tabular}{|c|c|c|c|c|}
\hline \multirow{2}{*}{\multicolumn{2}{|c|}{ Cannabis Indica. }} & \multirow{2}{*}{\multicolumn{2}{|c|}{$\begin{array}{c}\text { Percent } \\
\text { total ash } \\
13.82\end{array}$}} & \multirow[b]{2}{*}{$7.35 \%$ seeds } \\
\hline & & & & \\
\hline " & $"$ & & 13.05 & $4.16 \%$ \\
\hline “ & $"$ & & 15.05 & $4.41 \%$ \\
\hline “" & “ & & 14.20 & $5.76 \%$ \\
\hline " & “ & $\ldots$ & 14.70 & $4.50 \% " “$ \\
\hline$"$ & “ & ...... & 14.50 & $5.30 \% "$ \\
\hline$"$ & “ & & 13.80 & $9.40 \% "$ \\
\hline “ & “ & & 13.20 & $2.55 \%$ \\
\hline$"$ & $"$ & & 13.30 & $3.88 \% "$ \\
\hline
\end{tabular}

Maines, E. I., Joụr. A. Pr. A., Vol. 3, p. 424.

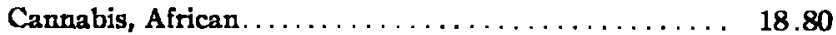

" India ...................... 14.00 to 20.80

LaWall, C. H., Procazdngs A. Pz. A., Vol. 58, p. 751.

Cannabis Indica................... 24.00, 18.04, 14.80, 9.60

Digest of Comments on U. S. P. \& N. F.

1906-Roder, P.-Indian Cannabis............ 13.94

$1907-"$ " $" \quad$ " $\quad \ldots \ldots \ldots \ldots \ldots \ldots \ldots$ 16.68-4 samples, 12.56 to

1909 -Evans Sons Lescher \& Webb, report one sample

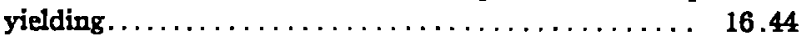

1912-Riedel, J. D." Cannabis, total ash........ 6.0 to 7.1 : acid insol. 2.4

Nitardy, F. W., “U. S. P. Bul. Sub-Comm. No. 5," p. 27... 12.0, 14.7

*Probably seed.

The use of American Cannabis has developed within the last few years. The above quoted results are almost entirely on the imported drug. Manufacturers report at this time that the American drug has almost entirely replaced the imported article. The results of this work seem to make it advisable that an acid-insoluble ash standard be adopted for Cannabis. Probably 4 or 4.5 percent would be satisfactory. The present standard of not more than 10 percent of fruits, seeds and other organic foreign matter should be retained and made more stringent, if conditions will permit.

Drpartument of Pharmacognosy,

Colifiog of Pharmacy, Univ. of Mnns.

\section{THE SIGNIFICANCE OF EDUCATION.* \\ BY WIILIAM H. CARPENTER, ${ }^{1}$ PH.D.}

In making any definition of education, or in attempting any predication of its purpose and results, we must, of course, at the beginning fully recognize the fact that in the life of the professional man, the lawyer, the physician, or the pharmacist, there are two elements involved, his education in his profession, on the one side, and his liberal education, on the other, or what we might properly call, at least from a certain standpoint, his special and his general education. My contention

- Parts of an address delivered at the Centennial Exercises of the Philadelphia College of 'Pharmacy and Science, June 14, 1921. Reprinted from American Journal of Pharmacy, August 1921.

1 Provont of Cölumbla Univenitty. 